\title{
Unpacking Teacher's Self-understanding in Technology Use during COVID-19 Pandemic
}

DOI: https://doi.org/10.47175/rielsj.v2i3.273

\begin{abstract}
| Fatimah Zahro Assidiqoh ${ }^{1, *}$ | Dewi Rochsantiningsih ${ }^{2}$ | Nur Arifah Drajati ${ }^{3}$ |
${ }^{123}$ Department of Teacher

Training and Education

faculty, Universitas Sebelas

Maret, Surakarta, Indonesia

*zahroassidiq02@student.uns.ac id

ABSTRACT

The spread of Covid-19 virus has suddenly forced face-to-face learning into online learning. These sudden changes give impacts to professional teaching and learning practices of teacher, teacher not only gives the material but also use technology maximally during this pandemic. The role of teachers and their professional self-understanding has become increasingly complex. This current study led to know about the teacher's self-understanding in the use of technology during the pandemic. Based on the purpose of the study, this study adopted a small-scale case study with one participant who is an EFL teacher from one of private senior high school in Surakarta, Indonesia. This case study used semi-structure interviews and classroom observations for collecting data techniques. To collect the data, researcher used teacher's selfunderstanding theory from Kelchtermans (1993). These teacher's self-understanding has five components, (1) self-image; (2) selfesteem; (3) task-perception; (4) job motivation; and (5) future perspective. After collecting the data, researcher applied an interactive model analysis. The results showed that (1) teacher's self-understanding in the use of technology becomes more positive. This understanding brings teacher to become part of booster teaches conducted by The Ministry of Education and Culture, and (2) the inclusion of informal, self-initiated, and self-regulated procedures has supported the modifications of these components of teacher's self-understanding when she used technology. KEYWORDS; COVID-19 pandemic; EFL teacher; self-understanding; technology use.
\end{abstract}

\section{INTRODUCTION}

The first incidence of Covid-19 in Indonesia has been discovered since March 2020. The Ministry of Education and Culture published Regulation Number 4 on March 24, 2020. This regulation stated that teachings from primary school to higher education must be conducted at distance learning. The notion has been forced learning in the classroom into distance learning (Miguel, et al, 2021; Feizi \& Bakhtiarvand, 2020). In this circumstance, teachers' roles have changed dramatically (Bao, 2020; Zayapragassarazan, 2020). The teacher experiences with changes in the educational system influence EFL teachers' professional practice (Allen, 2020). It makes teachers feel compelled to engage in online instructional techniques (Bao, 2020; Zayapragassarazan, 2020). Although, in the twenty-first century, technology and internet tools have revolutionized the teaching and learning process, not all teachers have taken use of them. The mixed learning system is an option. However, certain schools with specific instructor requirements carry out the mixed learning system (Wong, 2019). But in this pandemic case, all teachers must implement technology wholly and it presents a challenge for teachers. 
Preliminary investigation was conducted to find the challenges of teachers in their professional lives and work during COVID-19 Pandemic. In terms of their professional lives and employment, teachers are going through a particularly demanding time (Allen, J., Rowan, L., \& Singh, P, 2020). The rapid adoption of online learning models allows students to participate in learning from early childhood to higher education, which has a significant increase in the workload of educators. They not only strive to carry online teaching materials and content, but also to master the necessary materials use. Due to a lack of sources, student directors, and workload presentations, most teachers face enormous difficulties. It adds to stress and burnout. (Robosa, et al, 2021). These problems bring the teacher into critical incidents. Thus, critical events are circumstances that put a teacher's professional self to the strain (Kelchtermans, 2005). Perceptions, attitudes, and notions about herself are thoroughly questioned. As a teacher, one must examine their choices and personal priorities. One must make decisions that will have an impact on one's professional biography in the future. Teachers will consider these events as essential in their professional development in the future. The concepts crucial incidents and critical episodes are particularly fascinating because they are linked to changes in professional behavior. As a result of some critical occurrences, a teacher's typical approach to dealing with new obstacles must be changed.

Second result of preliminary study finds that online space and technology use have introduced additional layers of teaching and learning complexity (Bulfin \& Johnson, 2017; Mishra \& Koehler, 2006; Nemorin \& Orlando, 2013) by changing the situations and teaching and learning processes as well as the positions, perceptions, strength, and capacity of instructional contemporary education. The role of instructurs and their professional selfunderstanding has become increasingly complex, involving teachers in regular micropolitical plans and interventions in teaching (Kelchtermans, 2007). Teachers' selfunderstanding changes, it influences the choices for action (Keltchermans, 2018). It brings a question on how a teaching and learning practice during pandemic, what the teacher brings the process only into transition or enhances the student by using the technology. The use of technology to reconstruct or enhance actual devices in learning assignments and teaching practices are called enhancement, and the term "transformation" refers to the teacher's ability to create new learning possibilities, which is impossible outwardly utilizing technology (Kirkland, 2014). It pertains to Substitution, Augmentation, Modification, and Redefinition (SAMR) paradigm, which states that properly utilizing technology entails developing rich tasks that reimagine old learning methods and provide chances that would not otherwise exist (Puetendera, 2013).

Therefore, this current research has to be investigated and articulated in order to increase teacher professional understanding of practice and establish relevant strategies to assist their students' learning and development during Covid-19 online teaching practices. It can be used as the reflection of teaching and learning practice (Henry, 2018; Wong, 2019). Reflection needs more further than just a set of abilities and experience; it also requires certain personalities, such as being open to problems in your practice, willing to review your practice, willing to take risks, and expose your own vulnerabilities (Berry, 2017; Ivanoyvva, 2016). Through reflection, it is possible to develop a greater awareness of oneself, including wherewith one-acts, what knows and does not understand, powers and weaknesses, and recesses between the other says and does. It also enables teachers to develop new abilities while polishing and strengthening existing ones, allowing them to boost student accomplishment throughout the teaching and learning process. (Fransson, 2017).

Many researchers have also investigated teacher self-understanding. Fransson (2018) concentrated on what digitalization meant for the development of Swedish educator selfunderstanding. The discoveries had shown that the instructor's self-understanding was 
worked out and changed because of the call for digitalization. Then, Yang (2019) focused on understanding Chinese language teachers' beliefs. Chinese language teachers place a high emphasis on linguistic talents, content knowledge, and pedagogical expertise, according to the data. Both primary Chinese educators and teachers of another language prefer to become a student-centered instruction approach. The newest, Franson and Norman (2021) navigated teachers' self-understanding of an upper secondary school teacher's attempt for implementing technology and discover appropriate professional learning practices. The data said how his assignments focus shifted over time, from teaching to improving, supporting colleagues' learning, and contributing to the professionalization of the educators community.

However, previous researchers have explored the significance of self-understanding of the teacher in a technological context and in normal circumstances. This current research tries to explore teacher self-understanding in the technology use in the context of COVID19 Pandemic. Moreover, unlike previous research which was commonly explored in China, Sweden, and Finland, this research will be conducted in the context of Indonesia and teachers' self-understanding is a new field in Indonesian teaching (Benson, 2017). Specifically, this research focuses on Indonesian teachers' self-understanding in the use of technology in the case of forced online learning regulation because of the COVID-19 pandemic from a case study perspective.

\section{RESEARCH METHODS}

This study was applied as a pilot to look into how teachers regarded themselves in their teaching practice during the COVID-19 epidemic using technology, with a single case study methodology chosen to support this preliminary investigation. (Yin, 2016). Data from a single participant was used based on that the participant's interpretation of their reflective practice constituted a unique case in a particular context (Yin, 2016). To recruit potential participants, an invitation was extended by email or phone connections within the researcher's professional networks. Only those who answered and expressed an interest in participating were contacted by the researcher.

The participant was a female teacher who had been teaching English for eleven years in one of the private senior high schools in Surakarta, Indonesia. She had experience in the use of technology from the first experience in teaching until now during COVID-19 Pandemic. She had participated in many activities given by both internal and external communities of practices as part of his professional growth in the use of technology. She had attended professional development workshops and seminars aimed at enriching teacher knowledge and capacity in ELT. She had actively participated on booster teacher conducted by The Ministry of Education and Culture and EFL teacher associations in Indonesia. For ethical reasons, she was given pseudonyms as Anna.

The study was conducted from February to May 2021. To answer the question, data were collected using semi-structured interview of approximately 45 minutes in three times. After getting permission, the interview was conducted by Zoom Meetings based on Professional self-understanding from Keltcherman, 1993, 2005) and the technology use. Professional self-understanding consists of (1) self-image, (2) self-esteem, (3) task perception, (4) job motivation, and (5) future perspective. Researcher used Indonesian then translate it to English, and record the interview. To support the data, researcher applied observation for two meetings to know the teaching practice of the participant.

After collecting the data, researcher employed an interactive model analysis from Miles et al. (2018). The steps for data analysis were data gathering, data condensation, data display, and conclusion drawing or verification. First, the researcher collected the data by using interviews, and classroom observations. The researchers then fine-tuned, sorted, and 
arranged the data so that a conclusion could be reached and verified. The researchers then presented the data as an orderly collection of data that led to the conclusion reached. Finally, experts reached a completion based on data that should have previously been reviewed and verified.

\section{RESULTS AND DISCUSSION}

Based on the analyses of the semi-structure interview and observations, findings were identified. These finding answer the research questions that are the teacher selfunderstanding in the use of technology in teaching practices during COVID-19 Pandemic. It will be explained in the below.

\section{Self-image}

Anna's self-image is formed by her desire to learn as well as her pupils' achievements in teaching and studying through Covid-19 online learning. Anna defines herself as a novice instructor in the midst of an 'induction stage,' as well as an explorer who is always looking for new materials and methods of use. Her motivation to improve and perform well, as well as her decision to give her students the best, are important aspects of her self-image. Anna devotes her working hours to staying current with technology, which is linked to her professionalism as a teacher. During the Pandemic, she works on identifying, mastering, and applying digital tools to increase students' learning. Anna revealed that:

\section{"Since this pandemic, I have spent a lot of time studying technologies that I never thought of before. I learn through workshops or I learn on my own through google. I did it so that I was able to improve learning bases on the needs of students and make them feel comfortable to study during this pandemic".}

Anna claims that the abilities of other teachers who are proficient at using current technology influence her professional self-image as a teacher. Anna said that she first matured conscious of the nature of teaching within YouTube and the description of digital media for instruction and teachers. Anna's understanding of the student's demands is a critical component of her own success story, as it illustrates her belief and abilities essentially a capable instructor. Anna's self-image is impacted by the responsibility of giving the best services to her students, not by her popularity. Anna reflects on how she perceives herself in relation to the role of "ICT Teacher." Her self-image is a blend of her own choices and the expectations of her students. Anna claimed:

"By understanding the needs of students, I am even more excited to practice my technology skills. Not only during this pandemic, this will be useful in the future. I never thought that my efforts to make You-tube learning because of my student would have this big impact".

Throughout her work as a teacher throughout the virus, Anna's self-image has shifted and manifested itself, particularly in regards to the usage of digital technologies. Anna's selfimage as an "ICT-teacher" was formed at her current school, where she was given the opportunity to deal with digital technologies in a targeted manner due to Pandemic and was also promoted as booster teacher due to her technological abilities. During this time, her own willingness to seek out improved digital technologies was a major element. This increased self-image triggered a cascade of new informal learning efforts, which resulted in even better self-image. Other research has discovered that images of "ideal teaching" or "ideal teachers" motivate teachers to learn (Appova and Arbaugh, 2018). Her promotion to booster teacher and self-directed professional learning helped to establish her reputation as a forward- 
thinking educator. As a result, her self-image has changed to that of a teacher who not only knows how to use digital technologies efficiently, but also actively searches out new educational technology to better her own skills. As an early adopter of digital technology for teaching and learning, Anna's image of the'elaborator' became a major component of her self-image and defined the path for her informal learning.

\section{Self-esteem}

The definition of teaching is based on others according to Anna's perspective. Because a teacher requires a pupil and colleagues. In order to strengthen her teaching skills and provide support to her students, she employs digital technology and digital surveys to collect and analyze student feedback. She wants the data to help both herself and her pupils, so she gave up paper questionnaires only used to provide feedback to teachers. Instead, she utilizes Google Forms, an interactive presentation software, to ask the students about their values, see what others are thinking, and write feedback. Digital surveys, YouTube, and visualization tools have received largely good responses from students and coworkers. These reactions are consistent with Anna's self-image as an "ICT instructor," resulting in a chain reaction and increased self-esteem. These experiences came in useful while Anna was encouraged to booster educator by her headmaster. It displayed evident to her that she was seen as a partial guide for other instructors, which gave her even more confidence. Anna said:

"The main components in teaching practice are teachers and students. The teacher acts as a facilitator for students. As facilitators we need to know the impressions of the students so that we know how the impact of learning on students. Therefore, at the end of every lesson I share a g-form containing things about myself, so that I can reflect on everything I have done in learning. All the positive and negative responses make me want to always improve my skills in technology. Moreover, the suggestion from my colleagues is very important too".

Anna's self-esteem is strengthened by her choice to practice evaluative digital tools in class, as well as the fact that her work raises her to role model status. These characteristics align with her self-perception as a new adopter, while also boosting her self-esteem as a resource for other teachers. As a result, she is more willing to engage in self-initiated and self-directed learning, which increases her drive to do so. Anna's employment motivation is linked to her self-esteem, in that gaining competence and proficiency inspires her to continue using digital technologies. The result shows that Anna's digital abilities and ability to autonomous designer and direct her own partial learning activities boost her self-esteem both as a teacher and while teaching. Anna said:
"Inever thought that this effort in using technology during this pandemic would bring me into a community on a large scale, and I had the opportunity to share what I've been doing and always improve my ability. It makes me feel responsible and unimportant is carrying out teaching practice. With the seriousness that I have, this will have such a wide impact".

Anna's basic self-esteem allows her to expound on digital technologies, test new technologies and instructional approaches, and investigate his formal teaching and learning processes on her own. Her self-esteem grew after she was nominated for the government's booster teacher award and was praised as a role model by students, the school administration, and Indonesian instructors. It has boosted her employment motivation and pushed her to progress further, as well as confirming that his formal practice orientation is lucrative and fulfilling. Self-efficacy, or enhanced self-esteem and motivation, has been linked to 
increased responsibility and the construction of unique knowledge mechanisms (Schunk, Pintrich, and Meece 2008). Anna emphasizes these points, as well as the fact that a accurate position and a great degree of self-efficacy have a significant impact on the adoption of digital technology, according to a study by Van Acker et al (2013).

\section{Job Motivation}

During the outbreak, Anna considered herself a proactive teacher, preparing courses and teaching methods, and using relevant tools to achieve positive results in teaching practice. Improving student learning and my responsibilities to their parents are the most motivating part of your job. When asked which is more important, her performance on the task or the performance of the students, she emphasized that her personal goals and ambitions for the students and their parents come first. On the other hand, Anna believes that teaching includes both internal and external stimuli, although it prioritizes internal value, the student plays an important role in motivating them to develop adequate strategies for informal, spontaneous and autonomous professional learning. She stated:

"I try to always be maximal and creative as possible in using technology all because of students and my responsibility for their parents. Because learning can only be carried out online, it takes a very long time. I have to be creative, because there are some aspects that are lost with the transfer of learning modes from face to face to online. I'm trying to bring back those missing aspects".

Anna's proofs for learning about digital technologies is correlated to her capacity to effectively use these tools in the classroom, for learning, and for administration. Anna has successfully digitized her classes and supports her pupils with the right tools and methodologies. Anna changed her teaching style in response to feedback from her students that she met their requirements. It motivates her to pursue unstructured, self-initiated, and self-directed expert learning. Both intrinsic and external stimuli help Anna stay motivated at work and give her direction for her professional development. Anna's excitement for her job inspires her to clarify her grasp of her obligations.

"In addition, I try to always be active in the learning community. This is very important, because by following it my spirit to always give the best will always be maintained. Even though it did not exist in the offline context but online. This is indeed very challenging, but I try to adapt to the situation."

Anna has had little opportunities for sufficient, contextualized, formal, professional development because she was a trailblazer in incorporating digital tools into training, studying, and administering. Specially created classes that met her special needs were not available offline, but were available online. It is undoubtedly a difficult circumstance for Anna, but she attempts to adjust. Anna self-initiated and self-directed informal learning practices become an essential part of his professional learning efforts. It is well known and documented that early adopter are forced to explore on their own to a large extent (Bennett 2012). Technology that she discovered on the internet, read about on You-Tube, and so on has influenced her schooling. As a result, she has received very little effective assistance and networking in her technical and pedagogical experimentation in the classroom setting. Although her students have been more thoughtful in this regard, the exchange of ideas and receiving feedback from colleagues has been limited.

Previous study has demonstrated the value of understanding of the students and comments for teachers utilizing technologies (Manca et al. 2016; Wright 2015). The school context provides the impetus for her to explore and develop her teaching - for the sake of the students and her own ideals of what constitutes "perfect teaching". Anna has learned about 
'ideal teaching' and what constitutes a 'good teacher' from external concepts such as structural circumstances and conceptual frames. These are transmitted through events such as the national teacher awards known as booster teacher. The other two structural factors are national supervision and teachers' expectation that they are responsible for their professional development (Fransson, 2017). Anna's task perception appears to have absorbed these elements. While she may not consider her formal schooling to constitute professional development, she says that it is ultimately her active decision to strive to better her skills as her practice expands.

\section{Task Perception}

During this pandemic, Anna perceives design, teaching, and assessment as complicated. Teachers must be able to navigate in addition to teaching and providing evaluations. Many other activities, such as administration, filled in the gaps, but Anna's sense of her responsibilities and teaching style did not reflect this. She tries to maximize her services to kids because the government has offered waivers in terms of teaching supplies. She argues that incorporating digital technology into education makes it more authentic, exciting, and achievable, as well as bridging the gap between classroom and real-world information. Because students can apply what they've learned in class to their daily lives, the knowledge they've obtained is useful. Anna said:
"Now my task is even more stringent, Ms. If the assignment is only written in nature, students can search the internet. Therefore, I prefer projects using technology. I give opportunities for the student to practice their knowledge by using their social media, such us Instagram, Tik-Tok, Facebook. The importance point is students' knowledge can be put into practice. Although in this case there has been before with teachers in terms of using Tik-Tok at the beginning of pandemic, I tried to explain Tik-Tok can be used for students' final projects. Tik-Tok is not only about entertainment, but can also be used for educational purposes. Finally, over time, her colleagues can understand it."

Anna believes that the primary responsibility of a teacher is to make content understandable through the use of relevant technology and methodologies. Digital technology, according to Anna, contributes to authenticity and offers considerable value to instruction, education, and administration. Anna's task perception includes locating acceptable technologies and developing appropriate teaching techniques and tasks. Taking accountability for her own professional practices has also become increasingly prominent in her task perspective. It encourages her to commit time and effort to activities such as looking for and learning about new technologies which is like their use in teaching, learning, and evaluation. She is attempting to compensate for the lack of formal professional development opportunities in technology and its implementation at the school and in the community by taking this approach. In contrast, Anna argues that she does not necessarily consider her informal learning to be professional advancement, despite the fact that she considers both formal and informal, self-initiation and self-regulating learning to be "normal" in her position. Over time, it has become more and more important for her to participate in the growth and innovation of the school, and to experiment with digital technology in teaching, learning, management, and professional learning, and is now more prominent in their mission vision.

Anna explains how her task perspective has shifted over time, shifting from a focus on learning to a stronger evidence supporting, and how this has influenced her work. As vital components of being, she takes responsibility for her own professional learning. A focus on her abilities and readiness to aid partners in their development and give contributions to the 
professionalization of the teaching community make her a "quality instructor". This has been a fundamental component of her work perception over time, prompting her to assume more informal responsibility for her own professional development, particularly since she is the first user of new technologies affordances and does not rely on subjects or co-workers. In doing so, she must assess the use of new materials and technologies, allowing her to spend some of her time experimenting, which has also led to her shifting task perspective. As a result, her task perception sustains her time spent learning as an early adopter, which is justified in terms of enhancing her job motivation and aligning with his partially modified task perception. According to the findings, instructors' task attitudes in regard to digital technology are shifting, However, this is frequently shown in phases of shifted expectations influencing instructors' actions and pedagogical orientations (Prestridge, 2017).

\section{Future Perspective}

Anna sees herself as an instructor will continue to expand her teaching and learning skills and will seek new ways to teach, learn, and use her learning management system in the future. Their participation in the professionalization of the teaching fellowship may increase, and expected work outside the high school classroom is not impossible; on the contrary, this is what she finds fascinating and desirable. One could pursue a future job as a content creator, master student, or educational consultant. All of these jobs necessitate ongoing professional development, much of which is informal and self-directed. Anna explained:

"In the future, I would like to have my own LMS, which will make it easier for students. So that students go as if they only bring one device, namely cellphones. In the future I want to share with students about technologies that can help them in learning English, using Artificial intelligence. To get there, I just want to empower myself, I want to take commitment for always spending my time for learning in community, and take a master in education if there is an opportunity later. Besides that, I want to be a content creator and an educational consultant in the issue of using technology in Indonesia".

\section{CONCLUSION}

During the Covid-19 epidemic, researchers looked studied how a teacher's selfunderstandings, as well as the part of self-image, self-esteem, job motivation, task perception, and future perspective, changed to become more further positive during teaching and learning activities. It has been established that the inclusion of informal, self-initiated, and self-acting procedures has supported the modifications of these components in relation to the study issue. It also showed how learning activities can bring results and success, improve their self-image, self-esteem and work motivation, and change their perceptions of tasks, emphasizing the use of technology as their "responsibility" to help colleagues and students in professional practices. Important teaching and learning activities have also broadened her view of future possibilities, both in terms of the benefits and drawbacks of digital technologies, as well as his professional career options. Anna exhibits agency and the ability to design approaches for her professional teaching and learning activities as a result of this. Finally, despite the fact that this is a small study, it accommodates vital understandings into this reciprocal interaction. However, because this research is focused on a specific nation circumstance, more research is needed to look into other aspects of teachers' self-understanding.

\section{ACKNOWLEDGMENT}

This study is my final assignment to finish my master's degree in education of English. I dedicate and respect EFL teacher because of their dedication taking as part of this research. 
I also sincerely thank my lecturers, who always support and give me suggestions for this research.

\section{REFERENCES}

Allen, Jeanne, Rowan, Leonie., \& Singh, Parlo. (2020). Teaching and teacher education in the time of COVID-19. Asia-Pacific Journal of Teacher Education, 48(3), 233-236. https://doi.org/10.1080/1359866X.2020.1752051.

Appova, A., \& F. Arbaugh. (2018). Teachers' Motivation to Learn: Implications for Supporting Professional Growth. Professional Development in Education, 44(1): 5-21. https://doi.org/10.1080/19415257.2017.1280524.

Bennett, E. (2012). Learning from the Early Adopters: Developing the Digital Practitioner Framework. Research in Learning Technology, 22(21453). https://doi.org/10.3402/rlt.v22.21453.

Benson, P. (2017). Autonomy in language teaching and learning. Language Teaching, 40(1), 21-40. https://doi.org/10.1017/S0261444806003958.

Bao, W. (2020). COVID -19 and online teaching in higher education: A case study of Peking University. Human Behavior and Emerging Technologies, 2(2), 113-115. https://doi.org/10.1002/hbe2.191.

Berry, Amanda. (2009). Professional self-understanding as expertise in teaching about teaching. Teachers and Teaching: theory and practice, 15(2), 305-318. https://doi.org/10.1080/13540600902875365.

Domina, T., Renzulli, L., Murray, B., Garza, A. N., \& Perez, L. (2021). Remote or Removed: Predicting Successful Engagement with Online Learning during COVID-19. Socius, 7. https://doi.org/10.1177/2378023120988200.

Feizi, F., \& Bakhtiarvand, M. (2020). Online Teaching of Rural Multi-Grade Classes in the Context of COVID-19: Proposing a Holistic Approach. Randwick International of Education and Linguistics Science Journal, 1(3), 246-252. https://doi.org/10.47175/rielsj.v1i3.134.

Fransson, G., Lindberg, O. J., \& Olofsson, A. D. (2017). From a student perspective, what constitutes a good (or less good) use of ICT in teaching? Education and Information Technologies, 23(1), 2155-2177. https://doi.org/10.1007/s10639-018-9708-4

Fransson, G., Lindberg, O. J., \& Olofsson, A. D. (2018): Digitalise and capitalise? Teachers' self-understanding in 21st-century teaching contexts. Oxford Review of Education, 45(1), 102-118. https://doi.org/10.1080/03054985.2018.1500357.

Fransson, Goran., \& Norman, Frederick. (2021). Exploring how a digitally skilled teacher's self-understanding influences his professional learning strategies. A research cooperation between a teacher and a researcher. Teacher Development, 1(1), 1-17. https://doi.org/10.1080/13664530.2021.1891131.

Kelchtermans, G. (1993). Getting the story, understanding the lives: From career stories to teacher professional development. Teachers and Teaching: Theory and Practice, 9(5), 443-456. https://doi.org/10.1016/0742-051X(93)90029-G.

Keltchermans, G. (2005). Teachers' emotions in educational reforms: Self-understanding, vulnerable, commitment, and micropolitical literacy. Teaching and Teacher Education, 21(1), 995-1006. https://doi.org/10.1016/j.tate.2005.06.009.

Kelchtermans, G. (2007). Macropolitics caught up in micropolitics: The case of the policy on quality control in Flanders (Belgium). Journal of Education Policy, 22(4), 471-491. https://doi.org/10.1080/02680930701390669. 
Kelchtermans, G. (2018). 'Should I stay or should I go?' Unpacking teacher attrition/retention as an educational issue. Teachers and Teaching: Theory \& Practice. 23(8), 961-977. https://doi.org/10.1080/13540602.2017.1379793.

Kirkland, Anita Brooks. (2014). "Models for Technology Integration in the Learning Commons." School Libraries in Canada 32(1), 14-18.

Manca, S., V. Grion, A. Armellini, and C. Devecchi. (2016). Editorial: Student Voice. Listening to Students to Improve Education through Digital Technologies. British Journal of Educational Technology, 48(5): 1075-1080. https://doi.org/10.1111/bjet.12568.

Miguel, F. F., Prudente, S. M., \& Aguja, E. S. (2021). Teachers Initiatives and Perceived Parental Involvement Practices among Filipino Junior High School Students. February. https://doi.org/10.1145/3450148.3450173.

Miles, M. B., Huberman, A. M., \& Saldaña, J. (2018). Qualitative data analysis: A methods sourcebook. California: Sage publications.

Mishra, P., \& Koehler, M. J. (2006). Technological pedagogical content knowledge: A framework for teacher knowledge. Teachers college record, 108(6), 1017. https://doi.org/10.1111/j.1467-9620.2006.00684.x.

Orlando, J. (2013). ICT-mediated practice and constructivist practices: Is this still the best plan for teachers' uses of ICT? Technology, Pedagogy and Education, 22, 231-246.

Puentedura, R. R. (2013). SAMR: Moving from enhancement to transformation. Retrieved from http://www.hippasus.com/rrpweblog/archives/000095.html

Prestridge, S. (2017). Examining the Shaping of Teachers' Pedagogical Orientation for the Use of Technology. Technology, Pedagogy and Education, 26(4): 367-381. https://doi.org/10.1080/1475939X.2016.1258369.

Schunk, D. H., P. R. Pintrich, and J. L. Meece. (2008). Motivation in Education: Theory, Research, and Applications. 3rd ed. Upper Saddle River, NJ: Pearson Education.

Toledo, G. A. (2021). Teachers' Perceptions on E-Media Adoption in Basic Electronics Technology. Randwick International of Education and Linguistics Science Journal, 2(1), 37-43. https://doi.org/10.47175/rielsj.v2i1.197

Uitto, et al. (2016). Peer group as a meeting place: reconstruction of teachers' selfunderstanding and the presence of vulnerability. International Journal of Education Research, 75(3), 7-16. https://doi.org/10.1016/j.ijer.2015.10.004.

Van Acker, F., H. van Buuren, K. Kreijns., \& M. Vermeulen. (2013). Why Teachers Use Digital Learning Materials: The Role of Self-Efficacy, Subjective Norm and Attitude. Education and Information Technologies, 18 (3): 495-514. https://doi.org/10.1007/s10639-011-9181-9.

Wong, R. (2019). Basis psychological needs of students in blended learning. Interactive Learning Environments, 27(1), 1-15. https://doi.org/10.1080/10494820.2019.1703010.

Yang, Juang. (2019). Understanding Chinese language teachers' beliefs about themselves and their students in an English context. System, 80(4), 73-82. https://doi.org/ 10.1016/j.system.2018.10.014.

Yin, Robert K. (2018). Case Study Research and applications: Design and Methods (6th ed.). SAGE Publications.

Zayabalaradjane Zayapragassarazan. (2020). COVID-19: Strategies for Online Engagement of Remote Learners. https://doi.org/10.7490/F1000RESEARCH.1117835.1. 